IIIIIIIIIIIIIIIIIIIIIIIIIIIII

$$
\text { ミニレビュー }
$$

IIIIIIIIIIIIIIIIIIIIIIIIIIIII

\title{
植物防御を標的としたアザミウマ忌避剂の開発”
}

安部 洋 ${ }^{1, *}$, 櫻井民 ${ }^{2}$, 大矢武志 ${ }^{3}$, 松浦昌平 ${ }^{4}$, 冨高保弘 ${ }^{5}$,

梅村賢司 ${ }^{6}$, 腰山雅 $己^{7}$, 津田新哉 ${ }^{2, \dagger}$, 三冨正 明 ${ }^{6}$

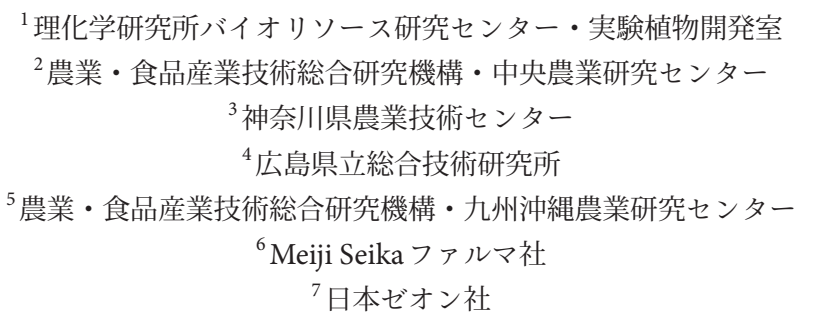

（2019年7月 5 日受理）

\section{Development of the thrips repellent}

\author{
Hiroshi Abe, ${ }^{1}$ Tamito Sakurai, ${ }^{2}$ Takeshi Ohya, ${ }^{3}$ Shohei Matsuura, ${ }^{4}$ Yasuhiro Tomitaka, ${ }^{5}$ \\ Kenji Umemura, ${ }^{6}$ Masami Koshiyama, ${ }^{7}$ Shinya Tsuda ${ }^{2}$ and Masaaki Mitomi ${ }^{6}$ \\ ${ }^{1}$ RIKEN BioResource Research Center, Tsukuba, Japan \\ ${ }^{2}$ NARO Central Region Agricultural Research Center, Tsukuba, Japan \\ ${ }^{3}$ Kanagawa Agricultural Technology Center, Kanagawa, Japan \\ ${ }^{4}$ Hiroshima Prefectural Technology Research Institute, Hiroshima, Japan \\ ${ }^{5}$ NARO Kyushu Okinawa Agricultural Research Center, Kumamoto, Japan \\ ${ }^{6}$ Meiji Seika Pharma Co. Ltd., Tokyo, Japan \\ ${ }^{7}$ Zeon Corporation, Tokyo, Japan
}

Keywords: thrips, repellent, plant defense, insecticide resistance.

\section{は じめに}

最近，持続的という表現を目にすることが増えてきた。国 連開発計画がかかげる持続可能な開発目標（SDGs：通称， グローバルゴールズ）などが良い例である．2050年には地 球人口が 98 億人に達すると言われており, 食糧生産の持続

\footnotetext{
\#第43回大会シンポジウムを取りまとめた解説.

* \% 305-0074 茨城県つくば市高野台3-1-1

E-mail: ahiroshi@rtc.riken.jp

†現所属 法政大学・生命科学部〔Present address: Hosei University Faculty of Bioscience and Applied Chemistry, Tokyo, Japan]

(c) 日本農薬学会
}

性は今後の人類に課された最も重要な問題の一つであること は疑いようがない. 作物生産を考えたとき, 病害および虫害 の問題は最重要要素となるが, 歴史的にみて, 病害防除を目 的とした病害抵抗性の作物育種は盛んに行われてきた一方 で，害虫防除は殺虫剤に大きく依存してきた。そのような 中, 殺虫剂に対する抵抗性を高度に発達させた難防除害虫の 問題が, 世界的に深刻なものとなっており, 持続的な作物生 産を脅かしている.今後, 殺虫剤だけに頼らない新たな害虫 防除技術の開発や新たな害虫抵抗性の品種育成が早急に望ま れる。

殺虫剂抵抗性を獲得し難防除化した害虫には，コナジラミ やハモグリバエ，ハダニなど多くの害虫種が存在するが，そ 


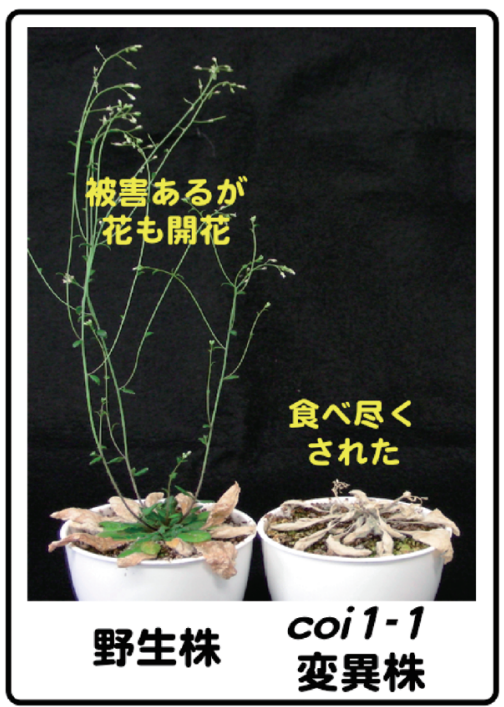

図1. ジャスモン酸防御とアザミウマ食害. シロイヌナズナ野 生型, 及びcoil-1変異体に対して, 20 頭のアザミウマ雌成虫を それぞれ放飼した. 写真は 2 週間後に撮影 (文献6より改変).

の中でもアザミウマによる被害は深刻である。アザミウマは 体長わずか $1-2 \mathrm{~mm}$ の微小な害虫であり，植物体上の奥まっ た狭い空間を好む性質を有しており, 殺虫剤抵抗性との関連 性も示唆されている．つまり，植物体上の奥まった空間に潜 んでいることにより，殺虫剤の散布が充分にアザミウマには 暴露されず，このことが殺虫剂抵抗性獲得リスクと関わって いるというのである. ${ }^{1)} し か も ， チ ョ ウ$ 目害虫などと異なり， アザミウマは移動性に優れた成虫期にも植物を加害する。こ のような生態様式はアザミウマの早期発見の困難さにつな がっている．高齢化の進む日本の農業生産現場において，ア ザミウマを目視で発見することは至難の技であり，非常に やっかいな存在である．さらに悪いことに，アザミウマ類は ウイルス病の媒介虫としても広く知られている。特に，ミカ ンキイロアザミウマは野菜や果物，そして花き類など数百種 を超える植物種を食害すると共に，トマト黄化えそウイルス （TSWV）やキク茎えきウイルス（CSNV）などのトスポウ イルスを媒介することから悪名高く, 新たな防除法の開発が

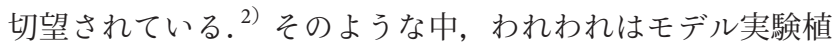
物のシロイヌナズナを用いることで, アザミウマに加害され た植物中で高まる防御反応のメカニズムと, 植物の防御がア ザミウマに及ぼす影響について解析を行ってきた．本ミニレ ビューにおいては，我々がこれまでに行った植物防御とアザ ミウマの行動についての一連の研究を概説する.さらには, 植物防御を活性化させることによるアザミウマ忌避剤の開発 についても紹介し, 今後の展開を論じたい.

\section{1. アザミウマに加害された植物における防御反応}

モデル実験植物のシロイヌナズナ（Arabidopsis thaliana） の全ゲノム配列が 2000 年に解読されて，今年で 20 年目とな
る.この 20 年の間に, 数多くの網羅的なリソースが急速に 整えられ，シロイヌナズナ全遺伝子の実に約 $95 \%$ 以上で遺 伝子破壊系統が整備されるに至っている（The Arabidopsis Genome Initiative, 2000)。このようなリソースは理研バイ オリソース研究センター（理研 BRC）をはじめとしたシロ イヌナズナのリソースセンターから容易に入手可能である. また，シロイヌナズナ全遺伝子の発現データや共発現情報， 様々な野生系統のゲノム情報やフェノタイピング情報など が閲覧できるデータベースの基盤整備も著しい。このよう に, 他植物には存在しない研究基盤を活用することで, 生命 現象のメカニズム解明を目指した様々な研究がシロイヌナズ ナを用いて現在, 行われている. 我々は, シロイヌナズナと ミカンキイロアザミウマ（Frankliniella occidentalis）をモデ ル系として，アザミウマ食害を受けた植物では何が起きてい るのか? 植物防御の視点から, 生物間相互作用メカニズム を解明し，得られた成果を実際のアザミウマ防除に活用する ことを目指して研究開発を行ってきた。チョウ目害虫に加害 された植物においては植物ホルモンのジャスモン酸制御によ り, 積極的な防御応答が誘導されることが広く知られてお り, ジャスモン酸防御機構と一般に言われている. チョウ目 害虫の食害様式は葉を咀嚼し食べ進んでいくが, 一方で, ア ザミウマの食害は口器で葉の表面を傷つけ, 滲み出てきた組 織液を吸汁する食害様式である. ${ }^{1)}$ 調べた結果, アザミウマ 食害に対する植物防御応答においてもジャスモン酸の影響が 大きく, アザミウマ食害を受けた植物ではジャスモン酸の内 生量が増大し, ジャスモン酸の制御により様々な防御関連の 遺伝子発現が誘導されていることがわかった。 ${ }^{3-5)}$ 興味深い ことに, 微小なアザミウマによる食害量は, チョウ目害虫に

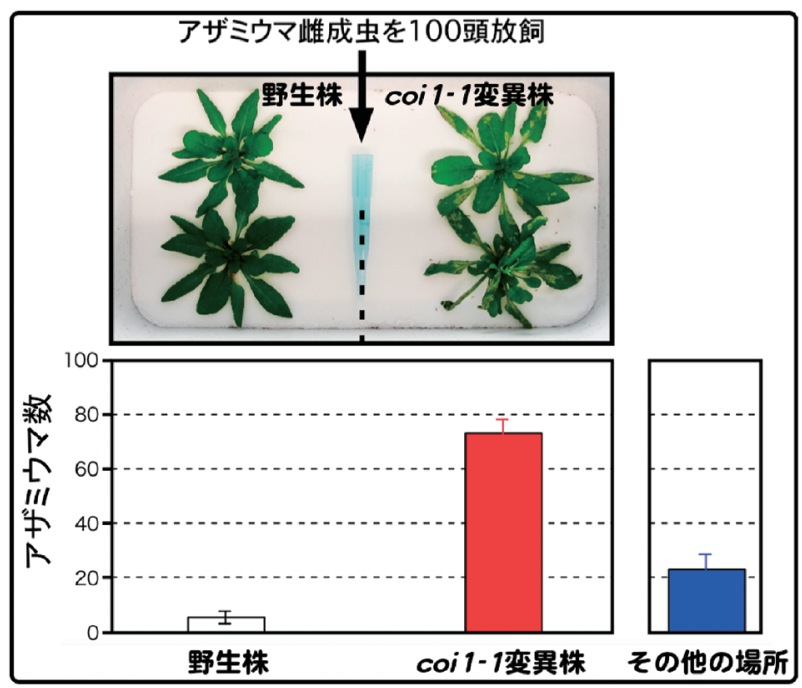

図2. ジャスモン酸防御とアザミウマ行動. シロイヌナズナ野 生型, 及びcoil-1変異体に対して, 100頭のアザミウマ雌成虫を 放飼. どちらの植物を選ぶのか選好性試験を行った。アザミウ マ数は2日後にカウントした (文献6より改変). 
よる食害量と比較すると明らかに少ないと思われるが，植物 のジャスモン酸防御応答を遺伝子発現で評価した場合, アザ ミウマ食害による遺伝子発現量は 2 倍以上高いことがわかっ た (安部ら未発表データ). 食害により組織自体が消失して しまうチョウ目害虫の食害と, 傷つきはするが組織自体は残 存するアザミウマ食害との違いなのかもしれない，次に我久 は，ジャスモン酸に対する感受性を消失したシロイヌナズナ coil-1変異体におけるアザミウマ被害について野生株での被 害と比較してみることにした。 その結果, 数值化するまでも ないほどにcoil-1変異体におけるアザミウマ被害は野生株で

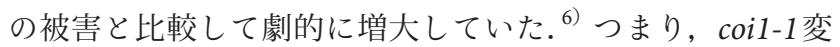
異体が食べ尽くされてしまっているのに対し，野生株では， 食害痕はあるものの，花も咲いていたのである（図1)。そ の後の詳細な解析により, coil-1変異体においては, ミカン キイロアザミウマの次世代個体群が爆発的に増大し，そのこ とが coil-1変異体での劇的な被害增大につながっていること がわかったそそして逆にアザミウマ放飼に先立ってジャスモ ン酸メチルを $100 \mu \mathrm{M}$ の濃度で植物に処理することでアザミ ウマ食害を顕著に軽減できることが示された。 ${ }^{6}$ ここのように, ジャスモン酸防御は，アザミウマに対して予想以上に大きな 影響を及ぼすことができることが判明したのである。

\section{2. 植物防御とアザミウマ行動}

病害と虫害を比較した場合, 昆虫である害虫には移動性が あるということは大きな違いといえるだろう。もしも害虫の 行動をコントロールすることができれば，おのずと害虫被害 は抑えることができる，言い方を変えると，害虫を作物から 遠ざけることができ机ば，そもそも害虫被害は生じないので ある.このような観点から, 我々は以下のようなモデル実験 系を構築した。つまり，アザミウマ食害に対してジャスモン 酸防御応答を示すシロイヌナズナ野生株と示さないcoil-1変 異株を一定間隔で配置し，その中心にアザミウマを放飼する ことで，その後のアザミウマの行動を評価した。そのの結果， 放飼 2 日後には，ほとんどのアザミウマがcoil-1変異株上に 存在することがわかった (図2). ${ }^{6}$ 結果として, coil-1変異 株と野生株を共存させると, アザミウマはcoil-1変異株を優 先的に加害するため, 野生株の被害は劇的に抑えられるこ とがわかった，一方で，アザミウマにシロイヌナズナ野生株 しか選択肢がなければ，アザミウマは野生株を充分に加害す る. 以上のことから植物防御レベルの異なる植物を組み合わ せることで，アザミウマを防御レベルの低い植物へと移動さ せることができ，防除したい植物を保護することができるの ではないかと考えた.7

ところでモデル植物を用いた室内試験から得たこのような 植物防御による害虫の行動制御という発想が, 実際の農業現 場において，通用するのであろうか？われわれは，野外に おいてアザミウマが媒介するトスポウイルスに感染した植物
に, 媒介虫であるアザミウマが誘引されるという現象に着目 した。 ${ }^{8)}$ 野外において, アザミウマの行動がウイルス感染に より実際に制御されていると考えられたからである。実際に 調べてみると，トスポウイルスに属するトマト黄化えそウイ ルス（TSWV）に感染させたシロイヌナズナと感染していな い健全なシロイヌナズナを一定間隔で配置し，その中心にア ザミウマを放飼することで，その後のアザミウマの行動を評 価したところ, 確かにウイルス感染植物にはアザミウマが誘 引されることが示された（図3)。そこで我々はトスポウイ ルスに感染したシロイヌナズナでは何が起きているのか? 植物生理学的な解析を詳細に実施した。 その結果, ウイルス 感染植物においては, ジャスモン酸とは異なる植物ホルモ ンであるサリチル酸の内生量が増大していることがわかっ た、サリチル酸は植物の病害応答を制御しており,このよう な防御はサリチル酸防御と呼ばれている。 そこで, ウイルス 感染の代わりにサリチル酸を処理することでアザミウマの行 動に対する影響を調べてみることにした，サリチル酸処理を した植物と, サリチル酸処理をしていない植物を一定間隔で 配置し，その中心にアザミウマを放飼したところ，放飼2日 後には, 有意に, サリチル酸を処理した植物にアザミウマは 多く生存していた。 ${ }^{6}$ サリチル酸防御はジャスモン酸防御と 拮抗的に作用することが広く知られている. ${ }^{9)}$ ジャスモン酸 を前もって処理することでアザミウマの食害を抑えることが できることは前述した，われわれは以前に，アザミウマの食

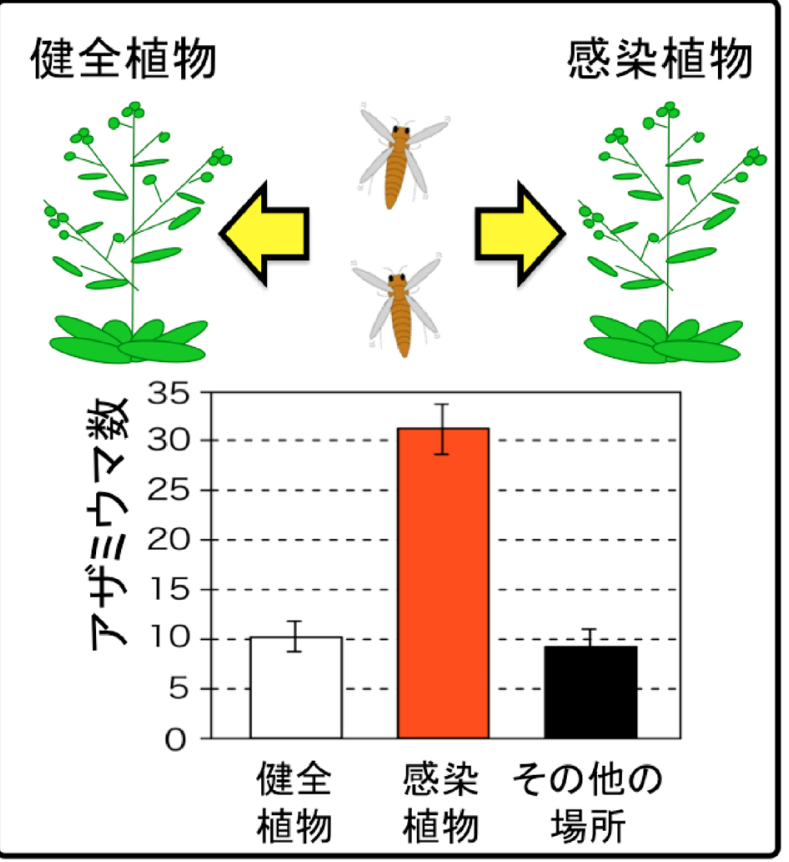

図3.トスポウイルス感染植物が有するアザミウマ誘引性. ト マト黄化えそウイルス（TSWV）に感染した植物と健全植物に 対して，50頭のアザミウマ雌成虫を放飼. どちらの植物を選ぶ のか選好性試験を行った．アザミウマ数は 2 日後にカウントした (文献6より改変). 
害に対するサリチル酸防御の影響についても調べており，サ リチル酸の働きにより，アザミウマ食害を抑制するジャスモ

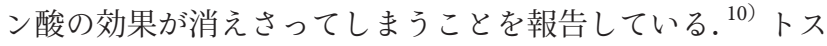
ポウイルスに感染した植物にアザミウマを放飼し，食害によ るジャスモン酸防御応答性遺伝子の発現を調べたところ, ウ イルスに感染していない植物と比較して，有意にその発現量 は減少していた。つまり，トスポウイルスに感染した植物で は，アザミウマ食害により植物で展開されるジャスモン酸防 御レベルが半減していたのである. ${ }^{11)}$ 以上のように，トスポ ウイルスは結果としてジャスモン酸防御を弱めることによ り，自らが感染している植物にアザミウマを誘引しているこ とがわかった。つまり，アザミウマは野外においても，植物 防御を敏感に感知し行動していると結論づけた。

\section{3. アザミウマ忌避剂の開発}

これまで，植物のジャスモン酸防御とアザミウマの行動制 御について概説してきたが，実際に我々は，野外において植 物にジャスモン酸を処理することにより，アザミウマ類を忌 避することができるのかについて試験を実施してみることに した。その結果，施設圃場においても野外圃場においても， 効果的にアザミウマ類を忌避することに成功した（櫻井, 冨 高ら未発表データ)。そこで，実際にアザミウマの忌避剂開 発を開始するにあたり，ジャスモン酸あるいはその関連化合 物として唯一実用化されているn-propyl dihydrojasmonate （PDJ）に着目した.PDJは理化学研究所の瀬戸秀春博士に より合成されたジャスモン酸誘導体であり，現在はブドウ やリンゴ果実の着色を目的とした植物成長調整剂として実 用化されている（図4). ${ }^{12 ）}$ またジベレリンとともに作用させ ることでミカンの浮皮防止の目的でも広く使用されている. 2015年には農林水産省が選定した気候変動適応計画の適応 技術にも選定されており，安全性にも極めて優れた資材で ある.そこで，われわれはトマトを対象としてPDJ散布によ

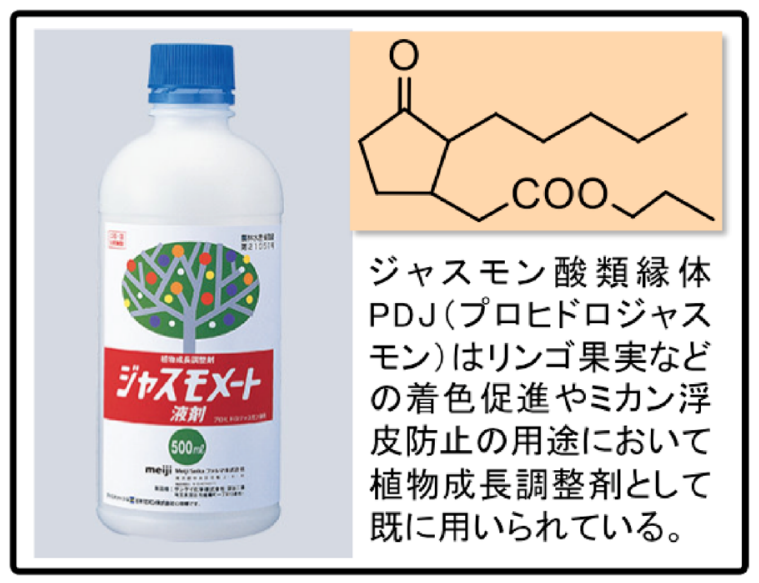

図4. 植物成長調整剤PDJ（プロヒドロジャスモン）。ジャスモ ン酸誘導体として唯一実用化されているプロヒドロジャスモン.
るミカンキイロアザミウマの忌避作用について，まず室内試 験を実施した。その結果, ジャスモン酸処理と同様にPDJ処 理によっても，アザミウマを忌避できることが明らかとなっ た。 また，PDJによるアザミウマ忌避効果はトマトだけでな く, キャベツ，キュウリ，キク，イチゴなどにおいても確認 することができた（安部ら未発表データ）。アブラナ科，ナ ス科，キク科，バラ科において同様な PDJ処理によるアザミ ウマ忌避効果が認められたことから, 忌避効果には植物種を 越えた共通性が作用していると考えられる。このように複数 作物種において，PDJによる忌避作用が認められた中で，わ れわれは,まずトマトに照準を絞り, 圃場での実証試験を実 施することとした，本来，日本ではトマトにおけるミカンキ イロアザミウマ被害は大きな問題とならないのだが，ここ数 年, トマトへの適応性に優れたミカンキイロアザミウマ（ト マト系統）の出現が認められていることから, 試験にはこの トマト系統を用いることにした，トマト栽培では, 育苗期か ら定植前後にかけての時期におけるアザミウマによるウイル ス病媒介が最も大きなリスクである。そこで, トマト育苗時 期から定植後に渡って 1 週間間隔でPDJ散布を行うこととし た。結果は極めて順調であり，PDJ散布により既存の殺虫剂 と同等にアザミウマを防除できることが明らかとなった（大 矢，松浦，櫻井ら未発表データ)。また，PDJ散布により， アザミウマが媒介するトスポウイルス病感染の抑制効果につ いても認められている(櫻井ら未発表データ).

\section{おわりに}

本ミニレビューで概説したアザミウマ忌避剂の開発は 2014年より始まった, 内閣府が主導するSIP（戦略的イ） ベーション創造プログラム）「次世代農林水産業創造技術： 持続可能な農業生産のための新たな総合的植物保護技術の開 発」からの支援を得て実施したものである．既にアザミウマ 忌避剤としての適用拡大申請も実施しており, 認可の取得を 待っているところである。農業生産において害虫防除は避け られない問題である. 現在, アザミウマやコナジラミなど幾 つかの害虫種においては, 殺虫剂抵抗性を高度に獲得した系 統の出現により, 従来の殺虫剂に大きく依存した害虫防除 の限界が生じている。このような中, 害虫を殺すのではな く, 行動を制するという新たな発想が重要になってくるので はないだろうか？ 本稿では触れなかったが, PDJには殺虫 性がないため, PDJによるアザミウマ忌避作用と天敵昆虫に よるアザミウマ補食効果との併用を行った場合の相性は非常 に高い. PDJは植物のジャスモン酸防御を高めることで, 虫 の「好き嫌い」といった本能に基づきアザミウマの行動を制 御できる剂である。ジャスモン酸防御は様々な遺伝子発現や 植物二次代謝などを経て複雑な生理現象により規定されてお り, ${ }^{13-15)}$ 化学薬品に対する抵抗性の発達とは無縁である.今 後, 殺虫剤との併用効果などについても試験を進め, 忌避剂 
を取り入れたこれまでにない新たな防除体系を構築していき たい. 同時に, PDJ散布によりアザミウマ以外の害虫をも忌 避できることが明らかとなってきているため, 今後, アザミ ウマ以外のどのような害虫種に対して忌避効果が認められる のか明らかにしていく予定である.

\section{引用 文 献}

1) M. P. Parrella: "Thrips Biology and Management," Plenum, New York, pp. 357-364, 1995.

2) A. E. Whitfield, D. E. Ullman and T. L. German: Annu. Rev. Phytopathol. 43, 459-489 (2005).

3) H. Abe, J. Ohnishi, M. Narusaka, S. Seo, Y. Narusaka, S. Tsuda and M. Koybayashi: Plant Cell Physiol. 49, 68-80 (2008a).

4) H. Abe, J. Ohnishi, M. Narusaka, S. Seo, Y. Narusaka, S. Tsuda and M. Koybayashi: Plant Signal. Behav. 3, 446-447 (2008b).

5) H. Abe, Y. Narusaka, I. Sasaki, K. Hatakeyama, M. Narusaka, K. Fukami-Kobayashi, S. Matsumoto and M. Kobayashi: DNA Res. 18, 277-289 (2011a).

6) H. Abe, T. Shimoda, J. Ohnishi, S. Kugimiya, M. Narusaka, S. Seo, Y. Narusaka, S. Tsuda and M. Koybayashi: BMC Plant Biol. 9, 97 (2009).

7) 安部 洋, 大西 純, 下田武志, 津田新哉, 小林正智 : 植物防疫 65: 215-220 (2011b).

8) P. C. Maris, N. N. Joosten, R. W. Goldbach and D. Peters: Phytopathology 94, 706-711 (2004).

9) T. Niki, I. Mitsuhara, S. Shigemi, N. Ohtsubo and Y. Ohashi: Plant Cell Physiol. 39, 500-507 (1998).

10) L. R. Antonio, S. H. Spoel, E. S. De Lange, H. Abe, M. Kobayashi, S. Tsuda, R. A. M. Welschen, T. Ritsema and C. M. J. Pieterse: Plant Physiol. 149, 1797-1809 (2009).

11) H. Abe, Y. Tomitaka, T. Shimoda, S. Seo, T. Sakurai, S. Kugimiya, S. Tsuda and M. Koybayashi: Plant Cell Physiol. 53, 204-212 (2012).

12) 腰山雅巳, 渡邊和紀, 藤澤 浩, 三冨正明, 今村圭一 : 植物の生 長調節 38: 35-47 (2006).

13) G. A. Howe and G. Jander: Annu. Rev. Plant Biol. 59, 41-66 (2008).

14) K. Okada, H. Abe and G. Arimura: Plant Cell Physiol. 56, 16-27 (2015).

15) H. Abe, K. Tateishi, S. Seo, S. Kugimiya, M. Yokota-Hirai, Y. Sawada, K. Yara, T. Shimoda and M. Kobayashi: Plant Physiol. 163, 1242-1253 (2013).

\footnotetext{
略 歴

安部 洋（あべひろし）

生年月日：1970年2月 12 日

最終学歴: 東京農工大学連合大学院農学研究科博士課程終了

研究テーマまたは主な職歴：植物防御を介した植物と害虫と の相互作用

趣味：楽器演奏
}

櫻井民人（さくらい たみと）

生年月日：1967年1月 11 日

最終学歴: 名古屋大学大学院農学研究科博士課程修了

研究テーマまたは主な職歴：農業病害虫に対する総合防御技 術開発

趣味：読書

大矢武志（おおや たけし）

生年月日：1965年9月 19日

最終学歴：埼玉大学大学院理工学研究科生化学専攻博士前期 課程修了

研究テーマまたは主な職歴：農業害虫に対する総合防除技術 開発

趣味：テニス, サーフィン

松浦昌平 (まつうら しょうへい)

生年月日：1965年1月 28 日

最終学歴：鹿児島大学大学院連合農学研究科博士課程修了

研究テーマまたは主な職歴：作物ウイルス, ウイロイド病害 の防除技術開発

趣味：ジャズギター演奏, 日本中世史を巡る旅

冨高保弘（とみたか やすひろ）

生年月日：1979年 8 月 5 日

最終学歴：鹿児島大学大学院連合農学研究科博士後期課程修了

研究テーマまたは主な職歴：植物ウイルスと媒介虫, 植物と の相互作用

趣味：カフェ巡り

梅村賢司（うめむら けんじ）

生年月日：1964年1月 24 日

最終学歴：名古屋大学大学院農学研究科修士課程

研究テーマまたは主な職歴：環境調和型農業資材の開発

趣味：ゴルフ，映画鑑賞

腰山雅巳（こしやままさみ）

生年月日：1957年1月26日

最終学歴：東北大学大学院薬学研究科博士課程修了

研究テーマまたは主な職歴：植物成長調整剂ジャスモン酸誘 導体PDJの実用化開発

趣味：テニス

津田新哉（つだしんや）

生年月日：1961年11月 5 日

最終学歴：東京農業大学大学院農学研究科博士前期課程修了

研究テーマまたは主な職歴: 植物ウイルスと媒介虫, 植物と の相互作用

趣味：居酒屋探訪

三冨正明（みとみ まさあき）

生年月日：1952年7月 28 日

最終学歴: 宇都宮大学大学院農学研究科修士課程終了

研究テーマまたは主な職歴：病虫害防除に関する農薬開発お よびプラントアクティベーター開発

趣味：読書, 家庭園芸, ウォーキング 